\title{
Qualitative Analysis of Factors Affecting Decision- Making Process of Infrastructure Project Selection
}

\author{
Seng Hansen ${ }^{1}$, Eric Too $^{2}$, Tiendung Le $^{3}$ \\ \{seng.hansen@gmail.com ${ }^{1}$ \} \\ RMIT University, Australia ${ }^{1,2,3}$
}

\begin{abstract}
In practice, there are several factors affecting the decision-making process of infrastructure project selection, which may influence the decision makers in making investment decisions. Due to its significance, these influencing factors are explored in this study using a qualitative approach consisting of twenty semi-structured interviews with industry experts in the Indonesian context. Thematic coding analysis was used to analyze the collected data. Thirteen influencing factors have successfully identified and categorized based on their similarities into four groups, namely: personal attributes, cognitive abilities, technical factors, and intervention issues. Understanding these influencing factors is crucial in infrastructure project planning and selection since it will allow the decision makers to identify foreseeable problems and take precautionary steps in order to arrive at sound decisions. Finally, this paper presents the current practice of decision-making process for infrastructure project selection and highlights the influencing factors as an important issue that exists in the current practice.
\end{abstract}

Keywords: Decision-Making, Indonesia, Influencing Factors, Infrastructure Project Selection, Thematic Analysis

\section{Introduction}

In practice, there are several factors influencing the decision-making process related to infrastructure project selection and prioritization. In this context, influencing factors are defined as factors that influence the decision makers in making infrastructure investment decisions. Understanding how these decision makers arrive at their decisions is a cognitive process characterized by learning and problem-solving abilities. Identifying these influencing factors are crucial to understand the nature of decision-making process during infrastructure project selection and prioritization. These factors may influence the process which ultimately will impact the quality of decisions and outcomes [1][2]. Thus, it has become the aim of this paper to identify these influencing factors which have not been studied previously.

\section{Method}

This paper follows a systematic qualitative method to analyze the interview data collected mainly from three ministries in Indonesia, i.e., the Ministry of Public Works and Housing (MPWH), the Ministry of Transportation (MT), and the Ministry of National Development Planning (MNDP/Bappenas). The systematic interview process consisted of eight steps. The 
first step is interview draft development where interview questions and protocol were designed. Interview questions were developed based on critical review of literature and is presented in a matrix shown in Table 1.

Table 1. Interview Questions Matrix

\begin{tabular}{cll}
\hline No & \multicolumn{1}{c}{ Interview Questions } & \multicolumn{1}{c}{ References } \\
\hline 1 & $\begin{array}{l}\text { How do you make decisions related to infrastructure } \\
\text { project selection? / What is your current practice in } \\
\text { making decisions related to infrastructure project } \\
\text { selection? }\end{array}$ & $\begin{array}{l}\text { Omar, Trigunarsyah and Johnny [3], } \\
\text { Priemus [4], Williams and Samset [5] }\end{array}$ \\
2 & $\begin{array}{l}\text { Is the decision-making process more judgmental or } \\
\text { rational? }\end{array}$ & Kolar [6], Priemus [4] \\
3 & $\begin{array}{l}\text { What are the factors influencing infrastructure project } \\
\text { selection decision-making process? }\end{array}$ & Dietrich [1], Nooraie [7] \\
4 & $\begin{array}{l}\text { How does the politic influence the selection process? } \\
\text { Annema, Mouter and Razaei [8], Giang } \\
\text { and Pheng [9], Lee [10], Priemus [4] }\end{array}$ \\
& $\begin{array}{l}\text { To what extent does cross sector influence } \\
\text { infrastructure project selection? }\end{array}$ & $\begin{array}{l}\text { Hampl [11], Hurwitz, Heaslip and } \\
\text { Moore [12] }\end{array}$ \\
\hline
\end{tabular}

The second step is conducting a pilot interview to ensure the appropriateness of interview questions and to help the authors to understand possible interview situations. The third step is determining interview size and target respondents. Interview size mainly depends on data saturation when the actual interviews have been conducted. Meanwhile, the target respondents are those who meet these three criteria: (1) professionals working at the relevant ministries or agencies, (2) majored in a construction-related educational background, and (3) experienced in infrastructure project planning and/or selection.

This is followed by conducting the actual interviews. Twenty semi-structured interviews were conducted within four months period. Table 2 presents the profiles of expert respondents. The average interview duration was 48.45 minutes. All interviews were recorded using a voice recorder. Next, the interview records in audio files were transcribed into twenty written transcripts. Since the interviews were conducted in Bahasa Indonesia, the next step is to translate these written transcripts into English. These final transcripts were exported to NVivo12. The seventh step is to analyze these interview data using a structured thematic analysis technique which consisted of six phases: familiarization, initial coding, themes development, review, naming, and findings identification [13]. In last step, all findings were discussed and reported.

Table 2. Expert Respondents' Profile

\begin{tabular}{cccccc}
\hline Code & Affiliation & Education & Experience & Job Position & Gender \\
\hline E-1 & MNDP & Master & 15 years & Planning Officer & Male \\
E-2 & MPWH & Master & 11 years & PPK & Male \\
E-3 & MPWH & Master & >20 years & Head of Department & Male \\
E-4 & MT & Master & 11 years & Head of Department & Male \\
E-5 & MPWH & Master & 12 years & PPK & Male \\
E-6 & University & Doctoral & $>20$ years & Assoc. Professor & Female \\
E-7 & MPWH & Master & 11 years & Head of Department & Male \\
E-8 & University & Master & 4 years & Lecturer & Male \\
E-9 & MPWH & Master & 8 years & Functional Officer & Female \\
E-10 & MPWH & Master & 13 years & Head of Department & Male \\
E-11 & MNDP & Master & 31 years & Planning Officer & Male \\
E-12 & MT & Master & 14 years & Head of Department & Male \\
E-13 & MT & Master & 9 years & Functional Officer & Female
\end{tabular}




\begin{tabular}{lccccc} 
E-14 & MPWH & Master & 10 years & Head of Department & Male \\
E-15 & MT & Master & 9 years & Head of Department & Female \\
E-16 & MPWH & Doctoral & 17 years & Head of Department & Male \\
E-17 & MT & Master & 10 years & Evaluator & Male \\
E-18 & MPWH & Doctoral & 24 years & Head of Department & Female \\
E-19 & MT & Master & 10 years & Programming & Female \\
E-20 & MPWH & Doctoral & 21 years & Head of Department & Male \\
\hline
\end{tabular}

\section{Results and Discussion}

Interview analysis has successfully identified 13 (thirteen) influencing factors in infrastructure project selection process. Based on the frequency, experience becomes the most frequent factor conveyed by the respondents. These influencing factors can be grouped into four categories based on their similarities, namely: (1) personal attributes, (2) cognitive abilities, (3) technical factors, and (4) intervention issues. Figure 1 below illustrates the four categories of influencing factor in infrastructure project selection process in Indonesia. These influencing factors can further be grouped into two major categories, namely: internal and external factors. Internal factors refer to influencing factors within the organization. They may influence decision makers during the decision-making process. Meanwhile, external factors refer to outside influences that can impact on the decision-making process. Because it comes from outside, these external factors are more difficult to manage than internal factors. Identification of these influencing factors will be useful in understanding how a decision is made by the decision makers.

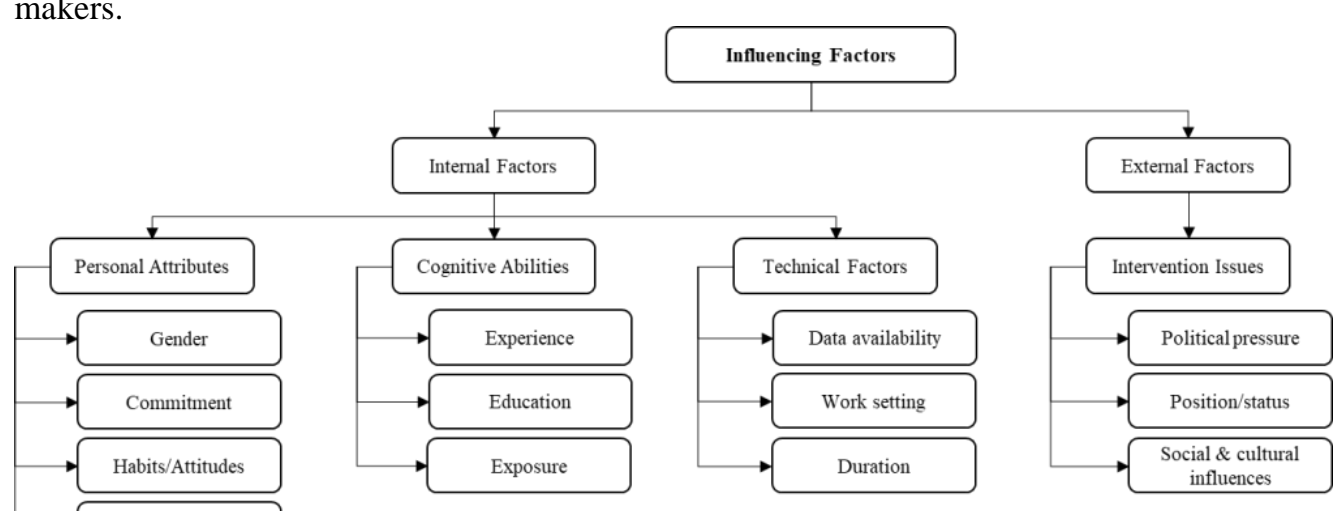

Fig. 1. Classification of influencing factors in infrastructure project selection decision-making process.

\subsection{Personal Attributes}

The first category is personal attributes which refer to characteristics of a person, in this context is a decision maker. These include gender, habits \& attitudes, commitment, and age. They are included as internal factors influencing.

Some respondents mentioned that gender might influence the decision-making process. This influence can be seen in the way of behaving between men and women in making decisions where men tend to be more rational than women who are more emotional. In other words, 
women are more concerned with feelings and dynamism during the decision-making process, while men assign more importance to the rational aspects such as analysis and justification of the decision [14]. However, there is no significant difference in terms of cognition. Both men and women respondents agreed that the decision-making process must go through an assessment process which includes obtaining information, gaining knowledge, conducting analysis, considering alternatives, and making logical decisions.

Another personal attribute identified from the interview analysis is habits \& attitudes. It refers to a regular tendency of decision makers in making decisions. This can be seen from settled way of thinking and practical habits that are always done by the decision makers. Furthermore, these habits $\&$ attitudes are also related to personal belief where if someone believes in what $\mathrm{s} / \mathrm{he}$ is doing, then s/he will tend to continue doing it until it develops into a habit or an attitude. According to Haris [2], this factor is complex in nature because it is directly related to the decision makers' personality.

Commitment is also an important factor influencing the decision-making process. With commitment, a decision maker will make decisions easier. However, the level of commitment may have a bad influence on the decision-making process. This happens when there is an escalation of commitment that forces the decision makers to make decisions based on irrational judgment because they have over-committed themselves [15]. This escalation of commitment is responsible for causing them to make risky decisions.

Last influencing factor regarding personal attributes is age differences. Age differences when making decisions can affect the quality of decisions made. This is also related to the level of maturity in dealing with problems and finding solutions. Here, older decision makers are considered more capable of carrying themselves out and calm in making decisions than younger decision makers who are more enthusiastic and not detailed. This may also be the reason why many respondents who occupy strategic positions can be categorized as older decision makers. However, older decision makers may become overconfident in making decisions [16] and thus making their decision analysis performance decline as well [17].

\subsection{Cognitive Abilities}

The second category is cognitive ability which refers to the ability to make decisions more precisely and efficiently. In this study context, if personal attributes are related to aspects that are inherently given, cognitive abilities reflect the gradual improvement of one's abilities. In other words, cognitive abilities can be learned, trained and developed. These include education, experience, and exposure.

The interview analysis provides that educational background can influence the decisionmaking process. This is mainly related to the education process in both formal and informal schools that emphasize thinking and reasoning skills. These skills will ultimately help the decision makers make decisions when they are working. Similarly, Kim et al. [18] found that education can improve the decision-making quality.

Besides that, experience is also one of the important factors forming cognitive abilities. In fact, it is the most frequent factor mentioned by the respondents. As an element that form a cognitive ability, experience (either good or bad) is a learning process that is obtained by making decisions. Sagi and Friedland [19] argued that people tend to avoid repeating bad experiences. By learning through past experiences, decision makers can polish their cognitive abilities so that when experiencing similar problems, they will be able to make better decisions. This finding goes hand in hand with Dietrich [1], Drury and McHugh [20] and Juliusson, Karlsson and Gärling [15] studies. 
The last influencing factor in cognitive category is exposure. Different from experience, exposure refers to the state of being exposed from phenomena or experiences which ultimately affects the decision-making process. In this study, there are two ways that exposure occurred. First is through career attainment. One's career development will cause him/her to be exposed with more experiences and broader new knowledge. This ultimately sharpens the cognitive abilities s/he has. Exposure can also occur through sharing experience/knowledge. This is done when someone asks for opinions or stories of experience from other people who have experienced similar problems before. In other words, s/he became exposed by other people experience. Exposure through sharing experience/knowledge can also affect a person's cognitive abilities which ultimately affects the decision-making process.

\subsection{Technical Factors}

The third category is technical factors which refer to technical aspects that influence the decision-making process. In the context of this study, technical factors are relevant to practical aspects during infrastructure project selection and prioritization processes. These include data availability, duration or length of time to make decisions, and work setting.

Data availability can affect decision makers in making decisions. If during the decisionmaking process it turns out that the data to be processed as input material for consideration to assess alternatives is not available, insufficient or in poor quality, this can affect the duration of decision making and the quality of the decisions taken. Similarly, Drury and McHugh [20] and Haris [2] found that data availability is an important influencing factor in making decision.

On the other hand, the duration to make decisions can also influence decision makers in making decisions. Too short duration may cause the decision makers to make decisions in a hurry. Meanwhile, long duration does not mean produce better decisions. Thus, time magnitude may lead to both negative and positive consequences [21].

The last factor in the technical category is work setting. In the context of this study, work setting refers to the working environment that is formed in the organization where the decision makers work. This working environment can influence the decision-making process. For example: Is there a clear infrastructure project proposal selection procedure provided? Has authority been clearly established? or Is there a decision-making framework or decision-making tool that can be used to help infrastructure project selection and prioritization process?

\subsection{Intervention Issues}

The last category is intervention which refers to the factors that influence the decisionmaking process through interference. The factors included in this category are also external factors because intervention is usually from outside the organization involved as decision makers in selecting and prioritizing infrastructure projects. This category includes political pressure, position/status, and socio-cultural influences.

Intervention in the form of political pressure can certainly influence decision-making process for infrastructure project selection. This is quite common in Indonesia as stated by several respondents. Political pressure occurs because there are interests from political actors in Indonesia who intervene the process of selecting and prioritizing infrastructure projects. In their study, Giang and Pheng [9] argued that political leaders can use infrastructure investment to secure their political positions. This may cause politicized decision-making rather than rationalized decision-making process during infrastructure project selection.

Next, there is a job position/status factor. The higher the position or status of a person, the easier s/he may intervene. Supervisors who are outside the selection team may have undue 
influence due to their seniority/status [20]. They can give interventions related to the methods, procedures and results of the selection made. If this continues to be carried out without proper justification, it can damage the existing project selection procedures.

The last is socio-cultural influences which can also influence the decision-making process. In the context of this study, socio-cultural influences refer to customs and values which become characteristic of a society. There have been many studies show that socio-cultural influences decision-making practice. As part of a community, decision makers are influenced by local socio-cultural values that may different from other places. This will ultimately influence decision-making processes such as: collectivism vs. individualism, dependent vs. independent decision-making manners, risk taking vs. risk avoidance, etc.

\section{Conclusion}

In conclusion, this study has succeeded in identifying several factors influencing the decision makers in selecting and prioritizing infrastructure projects in the Indonesian context. The selection and prioritization of infrastructure projects as a decision-making process is a cognitive process experienced by the decision makers. Thirteen influencing factors has been discussed with experience being the main factor conveyed by the expert respondents. However, experience is not the only factor that may determine the selection decisions. Understanding these influencing factors are important to understand how decision makers make decisions and ultimately what decisions are made. In other words, these factors may influence the decisionmaking process which at the end will impact the quality of decisions and outcomes. Finally, the findings of this study also facilitate further quantitative research based on the identified indicators.

\section{Acknowledgments}

The authors would like to express their gratitude to RMIT University, Universitas Agung Podomoro and Lembaga Pengelola Dana Pendidikan Republik Indonesia (LPDP) for supporting this research.

\section{References}

[1] C. Dietrich, "Decision making: Factors that influence decision making, heuristics used, and decision outcomes," Inq. J., vol. 2, no. 02, 2010.

[2] I. Haris, "Determinant factors of decision making process in higher education institution (A case of state University of Gorontalo, Indonesia)," Glob. J. Manag. Bus. Res., vol. 12, no. 18, 2012.

[3] M. Omar, B. Trigunarsyah, and J. Wong, "Infrastructure project planning decision making: challenges for decision support system applications," in Proceedings of the 7th Asian Pacific Structural Engineering and Construction Conference \& 2nd European Asian Civil Engineering Forum, 2009, pp. 146-152.

[4] H. Priemus, "Decision-making on mega-projects: Drifting on political discontinuity and market dynamics," Eur. J. Transp. Infrastruct. Res., vol. 10, no. 1, 2010.

[5] T. Williams and K. Samset, "Issues in front-end decision making on projects," Proj. Manag. J., vol. 41, no. 2, pp. 38-49, 2010.

[6] D. Kolar, "Improving the Link between Project Management and Strategy to Optimise Project 
Success," Unpubl. Dr. Diss. Melb. RMIT Univ., 2017.

[7] M. Nooraie, "Factors influencing strategic decision-making processes," Int. J. Acad. Res. Bus. Soc. Sci., vol. 2, no. 7, p. 405, 2012.

[8] J. A. Annema, N. Mouter, and J. Razaei, "Cost-benefit analysis (CBA), or multi-criteria decisionmaking (MCDM) or both: politicians' perspective in transport policy appraisal," Transp. Res. procedia, vol. 10, pp. 788-797, 2015.

[9] D. T. H. Giang and L. S. Pheng, "Critical factors affecting the efficient use of public investments in infrastructure in Vietnam," J. Infrastruct. Syst., vol. 21, no. 3, p. 5014007, 2015.

[10] H. Lee, "Policy Decision Making for Transportation Infrastructure: The Cases of High Speed Rails in the US," 2012.

[11] N. Hampl, "Energy investment decision-making under uncertainty: The influence of behavioral and social effects," St. Gall., 2012.

[12] D. Hurwitz, K. Heaslip, and D. Moore, "Relating transportation systems management and operations strategies to policy goals: A framework for quantitative decision making," Eng. Manag. J., vol. 24, no. 3, pp. 32-42, 2012.

[13] V. Braun and V. Clarke, "Using thematic analysis in psychology," Qual. Res. Psychol., vol. 3, no. 2, pp. 77-101, 2006.

[14] M. L. S. de Acedo Lizárraga, M. T. S. de Acedo Baquedano, and M. Cardelle-Elawar, "Factors that affect decision making: gender and age differences," Int. J. Psychol. Psychol. Ther., vol. 7, no. 3, pp. 381-391, 2007.

[15] E. Á. Juliusson, N. Karlsson, and T. Gärling, "Weighing the past and the future in decision making," Eur. J. Cogn. Psychol., vol. 17, no. 4, pp. 561-575, 2005.

[16] W. Bruine de Bruin, A. M. Parker, and B. Fischhoff, "Individual differences in adult decisionmaking competence.," J. Pers. Soc. Psychol., vol. 92, no. 5, p. 938, 2007.

[17] M. L. Finucane, C. K. Mertz, P. Slovic, and E. S. Schmidt, "Task complexity and older adults' decision-making competence.," Psychol. Aging, vol. 20, no. 1, p. 71, 2005.

[18] H. B. Kim, S. Choi, B. Kim, and C. Pop-Eleches, "The role of education interventions in improving economic rationality," Science (80-. )., vol. 362, no. 6410, pp. 83-86, 2018.

[19] A. Sagi and N. Friedland, "The cost of richness: The effect of the size and diversity of decision sets on post-decision regret.," J. Pers. Soc. Psychol., vol. 93, no. 4, p. 515, 2007.

[20] M. Drury and O. McHugh, "Factors that influence the decision-making process in agile project teams using scrum practices," in The 6th Int. Research Workshop on IT Project Management, a Pre-conference Workshop for the, 2011.

[21] F. Klapproth, "Time and decision making in humans," Cogn. Affect. Behav. Neurosci., vol. 8, no. 4, pp. 509-524, 2008. 


\section{Appendix}

Table 4. Distribution of main study selections by topic, determinants, and results

\begin{tabular}{|c|c|c|c|c|c|c|c|c|}
\hline \multirow[b]{2}{*}{ Year } & \multirow[b]{2}{*}{ Author } & \multicolumn{4}{|c|}{ Topic } & \multicolumn{2}{|c|}{ Determinants } & \multirow{2}{*}{$\begin{array}{c}\text { Outcomes } \\
\text { Benefits }\end{array}$} \\
\hline & & Gender & $\begin{array}{l}\text { Entrepreneurial } \\
\text { Potential }\end{array}$ & $\begin{array}{l}\text { Entrepreneurial } \\
\text { Mindset }\end{array}$ & $\begin{array}{l}\text { Entrepreneurial } \\
\text { Intention }\end{array}$ & Context & Definitions & \\
\hline 2006 & Liñán \& Chen & & & & $\mathrm{X}$ & $\mathrm{X}$ & & $\mathrm{X}$ \\
\hline 2009 & $\begin{array}{l}\text { Klasen \& Lamanna } \\
\text { Thompson }\end{array}$ & $\mathrm{X}$ & & & $\mathrm{X}$ & $\mathrm{X}$ & $\mathrm{X}$ & $\begin{array}{l}X \\
X \\
\end{array}$ \\
\hline 2011 & Kakkonen & & & & $\mathrm{X}$ & & $\mathrm{X}$ & $\mathrm{X}$ \\
\hline 2013 & $\begin{array}{l}\text { Chell } \\
\text { Gupta, Goktan \& Gunay } \\
\text { Mathisen \& Arnulf } \\
\text { Santos, Caetano \& Curral }\end{array}$ & $\mathrm{X}$ & $\begin{array}{l}\mathrm{X} \\
\mathrm{X} \\
\end{array}$ & $\mathrm{X}$ & & $\begin{array}{l}X \\
X \\
X \\
X\end{array}$ & & $\begin{array}{l}X \\
X \\
X \\
X\end{array}$ \\
\hline 2014 & UN, Women. & $\mathrm{X}$ & & & & & $\mathrm{X}$ & $\mathrm{X}$ \\
\hline 2015 & Varamäki et al. & & $\mathrm{X}$ & & & $\mathrm{X}$ & & $\mathrm{X}$ \\
\hline 2016 & $\begin{array}{l}\text { Karabulut } \\
\text { Shabbir, Shariff \& Shahzad }\end{array}$ & & $\begin{array}{l}X \\
X\end{array}$ & & & $\begin{array}{l}X \\
X\end{array}$ & & $\begin{array}{l}X \\
X\end{array}$ \\
\hline 2017 & Krueger \& Sussan & & & $\mathrm{X}$ & & & $\mathrm{X}$ & $\mathrm{X}$ \\
\hline 2018 & $\begin{array}{l}\text { Bosman \& Fernhaber } \\
\text { Dilli \& Westerhuis } \\
\text { Mamman et al. } \\
\text { Pauli \& Osowska }\end{array}$ & $\mathrm{X}$ & X & $\mathrm{X}$ & $\mathrm{X}$ & $X$ & $\begin{array}{l}X \\
X \\
X\end{array}$ & $\begin{array}{l}X \\
X \\
X \\
X\end{array}$ \\
\hline 2019 & $\begin{array}{l}\text { Bastian, Metcalfe \& Zali } \\
\text { Cao \& Ngob } \\
\text { Gieure, Benavides-Espinosa \& Dobón } \\
\text { Hatthakijphong \& Ting } \\
\text { Hyams-Ssekasi et al. } \\
\text { Irawan, Syakur \& Maududi } \\
\text { Madhavika, Onyeukwul \& Padmavathi } \\
\text { Sargani et al. } \\
\text { Suryawirawan }\end{array}$ & $\begin{array}{l}X \\
X \\
X\end{array}$ & $\begin{array}{l}X \\
X\end{array}$ & $\mathrm{X}$ & $\begin{array}{l}X \\
X \\
X\end{array}$ & $\begin{array}{l}X \\
X \\
X \\
X \\
X \\
X \\
X \\
X\end{array}$ & $\begin{array}{l}X \\
X \\
X\end{array}$ & $\begin{array}{l}X \\
X \\
X \\
X \\
X \\
X \\
X \\
X \\
X\end{array}$ \\
\hline
\end{tabular}




\begin{tabular}{|c|c|c|c|c|c|c|}
\hline & $\begin{array}{l}\text { Syeda et al. } \\
\text { Ward, Sánchez \& García }\end{array}$ & & $X$ & & & $\begin{array}{l}\mathrm{X} \\
\mathrm{X}\end{array}$ \\
\hline 2020 & $\begin{array}{l}\text { Abou, Hanafi \& Ali } \\
\text { Ahmeda et al. } \\
\text { Garcia, Lara \& López } \\
\text { Gómez et al. } \\
\text { Mujahid, Mubarik \& Naghavi }\end{array}$ & $X$ & $X$ & $\begin{array}{l}X \\
X\end{array}$ & $\begin{array}{l}X \\
X \\
X \\
X \\
X\end{array}$ & $\begin{array}{l}X \\
X \\
X \\
X \\
X\end{array}$ \\
\hline
\end{tabular}

